\title{
„Změna hrou": výzva k podávání příspěvků do zvláštního čísla
}

Hledáme pozitivní motivace k podpoře environmentální etiky ve vzdělávání

\section{Konference související s výzvou}

Tuto výzvu otevíráme $v$ souvislosti $\mathrm{s} 11$. Světovým kongresem o environmentální výchově ( $s$ podtitulem Stavíme mosty $v$ době klimatické nouze), který se bude konat ve dnech 14.-18. března 2022 v Praze - viz webové stránky konference.

\section{Obsah př́íspěvků}

V tomto zvláštním čísle chceme shromáždit doklady o úloze hry a spontánních aktivit při rozvíjení environmentální vnímavosti, podpoře empatie, a pěstování schopností potřebných při plánování a jednání ve prospěch prírody a v zájmu všech členů společnosti. Vítáme příspěvky ukazující, jak $v$ dětech povzbuzovat pozitivní myšlení, učit je chápat různorodost, znovu s nimi objevovat obr azy a narativy, stimulovat vize budoucnosti, pěstovat radost a touhu provázející úsilí o změnu $\mathrm{k}$ udržitelnému životu. Budeme společně hledat pedagogická východiska a postupy, které pomohou motivovat mladé lidi $\mathrm{k}$ tomu, aby si stanovili vlastní cíle a následně se jimi ř́dili $v$ osobním životě $\mathrm{i}$ $\checkmark$ rámci profesního působení. Tyto otázky mohou být nahlíženy z několika hledisek: psychologického nebo filozofického (zde vítáme úvahy o tom, jakou úlohu $v$ mentálním a tělesném rozvoji dítěte má možnost volně projevovat myšlenky a emoce $v$ přírodě, a proč je to relevantní a potřebné) a pedagogického (které představí nástroje a metody pro dosažení těchto vzdělávacích cílů, či vhodné prostředí a zapojené aktéry). Texty mohou být založeny na analytickém, hodnotícím přistupu a/nebo reflexi zkušeností z praxe. Souhrnně: kreativní př́stup pokládáme za jedno z témat tohoto zvláštního čísla, s ohledem na jeho důležitost při otevírání nových pohledů a podpoře mezioborových interakcí (nejen) ve vzdělávání; může být ale i metodou zpracování - vítáme zde kreativní a inovativní formáty rukopisů a dalších online příspěvků v různých žánrech (videa, ukázky aktivit, online výstavy...).

\section{Jak podat příspěvek:}

Jde o výzvu otevřenou pro všechny relevantní příspěvky, včetně těch, které nebudou prezentovány na konferenci WEEC 2022. Autoři mohou svůj návrh podat v období od května 2021 do dubna 2022 prostřednictvím online systému pro on-line odeslání př́spěvku do časopisu, nebo e-mailem na adresu Jana Dlouhá, jana.dlouha@czp.cuni.cz. Všechny rukopisy budou zaslány do recenzního řízení a zveřejněny, jakmile bude proces revizí dokončen; pak budou přiděleny do zvláštního čísla. Rukopisy podané po termínu nebo po skončení konference budou připraveny k publikaci v následujícím čísle. 